\title{
Sedimentary record of a Pleistocene ice-sheet interlobate zone (NE Poland)
}

\author{
Beata Gruszka*,1, Wojciech Morawski² \& Tomasz Zieliński ${ }^{1}$ \\ ${ }^{1}$ Institute of Geology, Adam Mickiewicz University, Maków Polnych 16, 61-606 Poznań, Poland \\ ${ }^{2}$ Polish Geological Institute, National Research Institute, Rakowiecka 4, 00-975 Warsaw, Poland \\ ${ }^{*}$ corresponding author e-mail: bgruszka@amu.edu.pl
}

\begin{abstract}
Well developed NE-SW trending corridors of outwash in NE Poland are associated with a series of lakes with a similar direction of elongation. The glaciofluvial corridor under study consists of parallel ridges with associated channels and kames. The deposits are flanked by till and hummocky terrain. The gravel ridges are composed of sand and gravel deposits that are cross-stratified, massive or graded, and that contain cut-and-fill structures and large intra-clasts of sand and gravel. Locally the deposits show normal faults. The succession of one of the ridges is interpreted to reflect the infilling of a braided channel in a crevasse. Sedimentation took place in some phases when the ice-sheet regime changed from active to stagnant. Sandy-gravel ridges occur within this complex perpendicular to the Weichselian icesheet margin.

The corridor is interpreted as an interlobate area in the zone between the Warmia and Mazury ice lobes. The braided-channel deposits are not comparable to typical Polish sandurs. The lithofacies characteristics show higher energy conditions, and the channels are deeper than those typical of Pleistocene lowland sandurs. The sand and gravel ridges are interpreted as interlobate eskers.
\end{abstract}

Keywords: interlobate sedimentation, outwash deposits, esker, Weichselian, NE Poland

\section{Introduction}

Interlobate zones are defined as areas between two ice-sheet lobes. Such zones are frequently reported from glaciated areas (Brennand \& Shaw, 1996; Carlson et al., 2005; Evans, 2000; Punkari, 1997; Stokes \& Clark, 2001). Two types of interlobate zones have been recognised. They are described in the literature as (1) interlobate joints, which are narrow zones between convergent ice flows, and (2) interlobate areas, which are wide areas of passive ice between adjacent ice streams (Punkari, 1997). The first setting is characterised by glaciofluvial deposits (in the form of outwash plains and eskers), whereas the other is characterised by moraine and glaciofluvial hummocky deposits. The first setting is thought to originate under tension conditions and a low debris content, whereas the second one reflects compressive and debris-rich conditions.

Sedimentation in interlobate zones is commonly dominated by glaciofluvial processes, but embraces a complex pattern of sedimentary environments, from subglacial tunnels through ice-walled channels and alluvial fans to subaqueous fans and glacial lakes. Allocation of the aforesaid environments is largely governed by the distribution of subaqueous and supraaqueous areas (Eronen \& Vesajoki, 
1988). The type of glaciomarginal forms and sedimentation is also related with the type of crevasse system in the marginal part of the ice lobes. The zone of transverse crevasses in the inner part of the marginal zone results, for instance, in De Geer moraines (Lundqvist, 1988). The zone of radial crevasses connected with a strongly fractured ice margin is dominated by subglacial and open channels, resulting in the development of eskers and deltas. This picture might be complicated by a fluctuating water level.

The complexity of the depositional environments in interlobate zones is expressed by the wide variety of glacigenic facies and landforms. The large sand and gravel complexes in interlobate zones are as a rule interpreted either as glaciofluvial outwash (Fraser, 1993) or as eskers attributed to subglacial drainage and associated sedimentation, first in a subglacial tunnel, and subsequently in an ice crevasse (Brennand \& Shaw, 1996; Lundqvist, 1999; Mokhtari Fard \& Gruszka, 2007). Subglacial tunnel deposits are accompanied by outwash fans, as found by Mäkinen (2003) and Mäkinen \& Palmu (2008) from decoupling Baltic Sea ice lobe. The Hurricana Moraine Complex in Ontario, Canada is believed to have originated in an interlobate valley-train (i.e. outwash) system (Veillette, 1994) or, alternatively, as a large eskerdominated glaciofluvial complex (Brennand \& Shaw, 1996). The Oak Ridges moraine in Ontario, Canada is interpreted as a subaqueous outwash fan deposited in an interlobate glacial lake, and was controlled by the water level (Paterson \& Cheel, 1997). Subglacial and crevasse deposits overlain by outwash fans of interlobate areas may be accompanied by supraglacial landforms resulting from the final disintegration of stagnant ice. Such a sub-to-supraglacial system fed by the meltwater from a subglacial tunnel and controlled by seasonal changes in discharge, bedrock, geometry and pattern of crevasses was interpreted as the origin of the Salpausselkä III moraine in Finland (Mäkinen \& Palmu, 2008). Readvancing ice overriding part of an interlobate deposit may produce a complex pattern of deformations (Weaver \& Arnaud, 2011), which make the genetic interpretation of such a deposit difficult.
Warren \& Ashley (1994) tried to simplify the definition of glaciofluvial ridges in an icemarginal environment. They classified these ridges on the basis of their morphology and the orientation of their crest with respect to the ice margin. In this classification, all ridges perpendicular to the ice margin are eskers, whereas those parallel to the ice margin are moraines. They also identified the various morphological elements of eskers (continuous esker ridges, beads, fans, etc.) that might be used to identify depositional relationships with respect to the subglacial conduits, ice-walled open channels, and ice-marginal settings. This classification is a useful tool for the classification of eskers on the basis of geomorphological signatures, but it does not integrate sedimentological information that might allow a further definition and refinement of esker genesis. The genetic types of eskers (Warren \& Ashley, 1994) can be distinguished only if the deposits belong to the narrow range of representative examples. Many eskers are complex, however, and require additional criteria to constrain their interpretation. Thus narrow interlobate glaciofluvial uplands may be interpreted as eskers, even though they may contain much more complex set of landforms.

Sedimentological interpretations based on lithofacies analyses of interlobate deposits are rare, especially for the Scandinavian ice sheet (Glanville, 1997; Lunkka \& Gibbard, 1996; Mäkinen, 2003; Mäkinen \& Palmu, 2008), and such studies have not been published at all for interlobate settings in Poland. The interlobate zone between the Mazurian and Warmian lobes of the Weichselian glaciation is well documented by geomorphological, geological and geophysical data (Morawski, 2009a; b). The zone is characterised by vertical discontinuities that are clear from geophysical data, and by a set of parallel glaciofluvial ridges of more or less N-S orientation. The landforms have been mapped, classified and interpreted by Morawski $(2009 a, b)$ as crevasse-fill landforms. The aim of the present contribution is to describe the sedimentary character of the ridges within this complex of glaciofluvial sediments. Based on the sedimentary facies, the depositional environment is interpreted. This analysis in- 
creases both the knowledge of the landforms and deposits within this interlobate area and the understanding of the processes that control ice-marginal interlobate deposition in the European lowlands.

\section{Geological and geomorphological setting}

The study site is located in the north-eastern part of Poland, in an area between the Warmia and Mazury provinces (terminology by Morawski, 2005) (Fig. 1). The Szczytno till plain (belonging to the Mazury province) is a relatively flat area with small, isolated hills up to $10 \mathrm{~m}$ high. These are dead-ice moraines built of poorly sorted sediments (both glaciofluvial and glacial) deposited in an ice-contact zone.
The Olsztyn till plain (belonging to the Warmia province) is situated at the west of the study area. Flat areas with glaciolacustrine sediments play a significant role in the geomorphology and geology of this plain. Low-relief areas on the till plains occur where silty glaciolacustrine deposits form the topmost sediments. The two provinces have a very different bedrock relief and thickness of the Quaternary. The traces left by glacial ice flows are also different (Morawski, 2009a). In seismic reflection profiles, the bedrock is cut by numerous faults interpreted to be related to vertical neotectonic block movements induced by successive ice-sheet advances (Morawski, 2009b).

A hummocky landscape, representing an interlobate area, lies between the two mentioned provinces. It is built of glaciofluvial deposits. The interlobate glaciofluvial complex is ap-

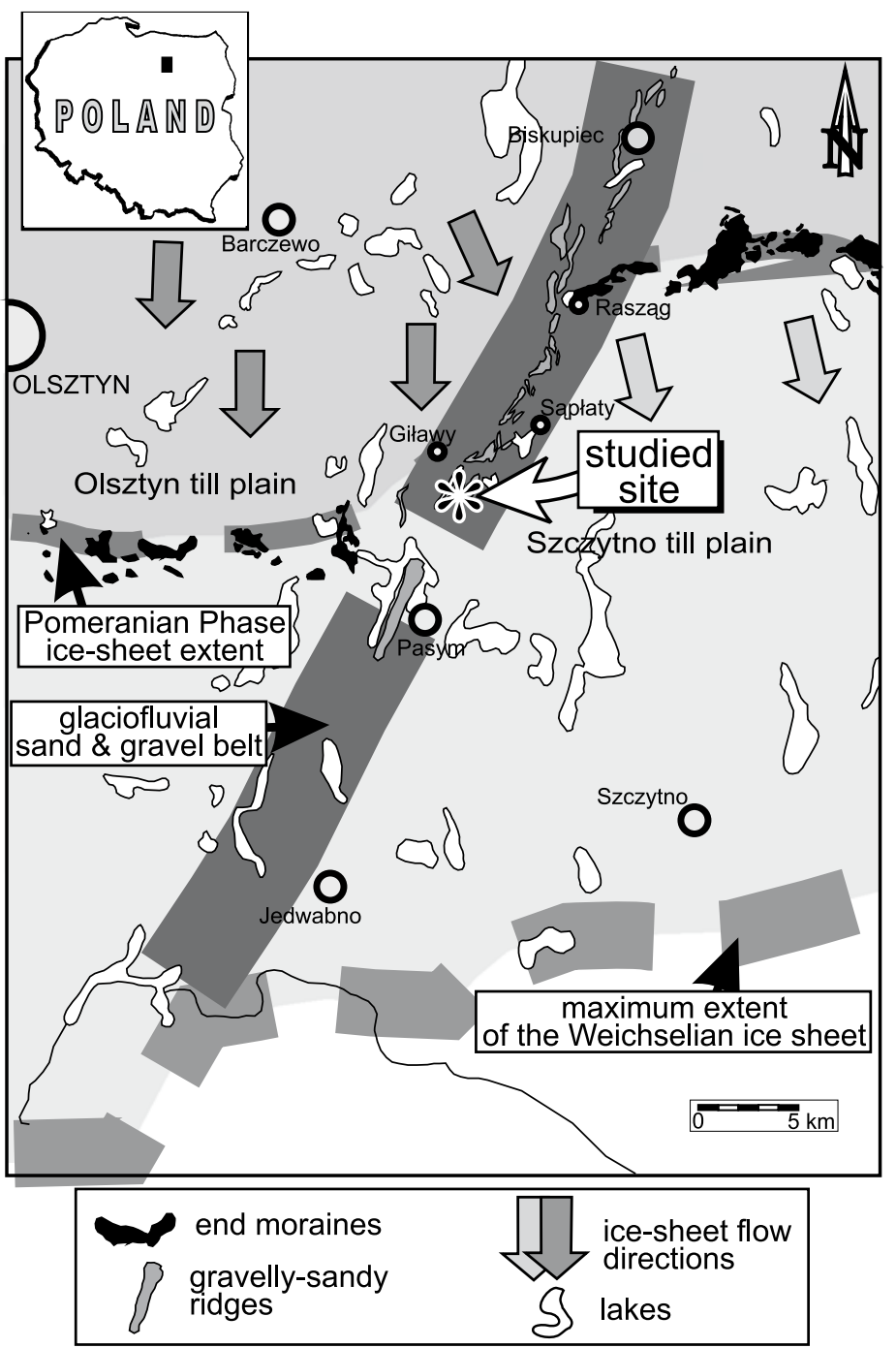

Fig. 1. Schematic palaeogeography of the glaciomarginal zone of the Weichselian ice sheet with the glaciofluvial belt developed between the two ice-sheet lobes. 


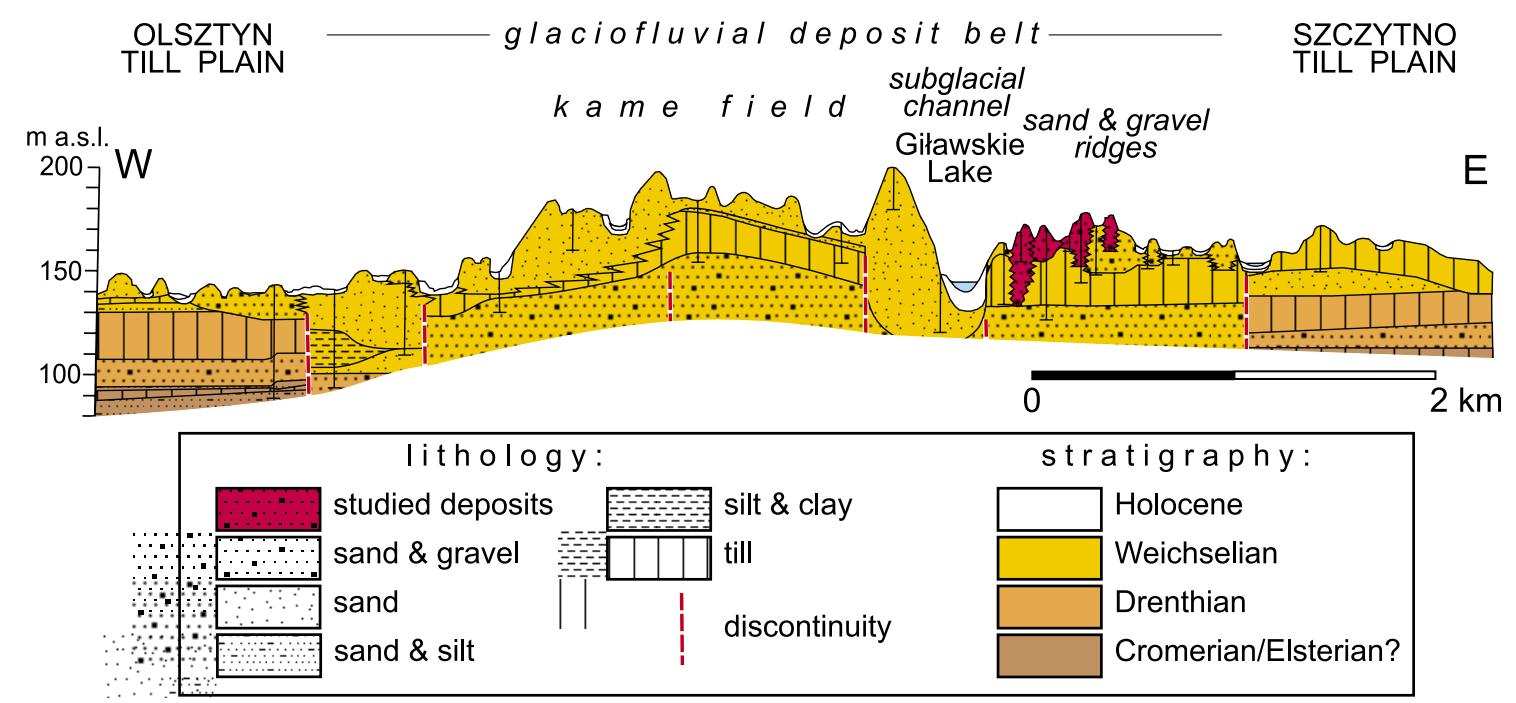

Fig. 2. Geological cross-section through the glaciofluvial sand and gravel belt (interlobate zone between the Olsztyn and Szczytno till plains.

prox. $60 \mathrm{~km}$ long and up to $2 \mathrm{~km}$ wide (Morawski, 2005). It has traditionally been interpreted as consisting of end-moraines (Mańkowska \& Słowański, 1978; 1980). Adjacent to the interlobate area, three till horizons occur, each varying from several to $20 \mathrm{~m}$ thick. The youngest till, forming the surface unit, dates from the

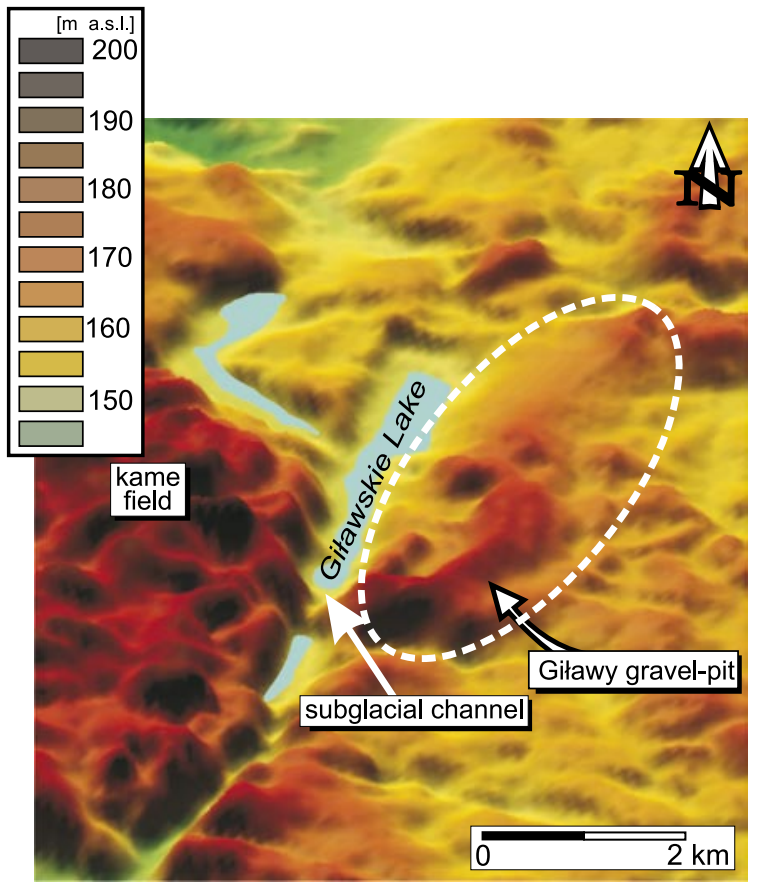

Fig. 3. Bird's-eye view from the south of a hill-shaded and colour-coded Digital Elevation Model (DEM) of the relief around the Giławy site. Note the contrasting landscape signatures that represent different geological terrains.
Weichselian (Vistulian in Polish stratigraphic nomenclature). The middle till horizon is Drenthian (Odranian) in age, and the age of the oldest till is still questionable; it may be Elsterian 1 (i.e. Sanian 2), or Glacial 2 of the Cromerian Complex (i.e. Nidanian). The till horizons are divided by glaciofluvial sandy or gravellysandy units with thicknesses from 5 to $15 \mathrm{~m}$.

Boreholes located close to the studied excavation penetrate only one till horizon of significant thickness (up to $20 \mathrm{~m}$ ) (Fig. 2); this till is of the Weichselian age. The older glacial horizons have been eroded away and were replaced by glaciofluvial deposits. These sandy-gravelly units are evidently thicker (up to $30 \mathrm{~m}$ ) than their glaciofluvial equivalents from the Szczytno and Olsztyn till plains (Fig. 2).

The sandy-gravelly ridges within the interlobate glaciofluvial zone are $0.4-1.3 \mathrm{~km}$ long, have an average width of $150 \mathrm{~m}$ and are commonly 10-15 m high (Fig. 4). The excavated hill at the Giławy aggregate site is one of the highest ridges in this area, with a local relief above the adjacent depression of $40 \mathrm{~m}$ (Fig. 3). The basal contact with the underlying till is abrupt and irregular, with local scours (channels) into the till of 10-30 m deep (Fig. 2). The maximum thickness of the sandy-gravelly unit is some 40 m.

Numerous kames occur west of the study site (Figs. 2, 3, 4). The kames are hills of isometric planform, with an average diameter of 


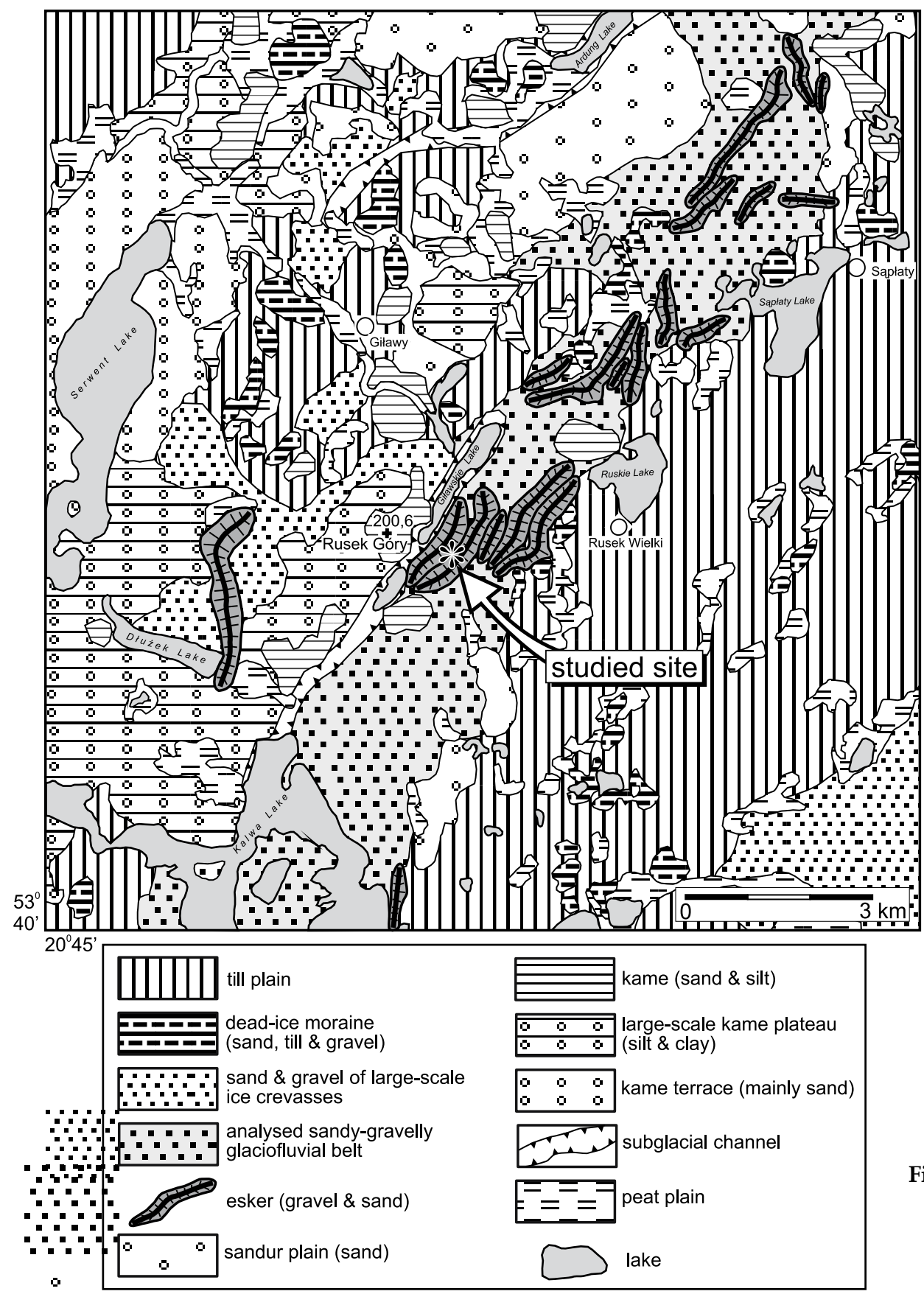

Fig. 4. Geological map of the glaciofluvial belt between the Olsztyn till plain (NW) and the Szczytno till plain (E and SE). several hundreds of metres and a height of up to $20 \mathrm{~m}$. They consist of fine-grained sands and silts of glaciolacustrine and/or glaciofluvial origin (Fig. 2).

The sandy-gravelly ridges are separated from the kame field by the Giławskie Lake glacial channel. The lake axis is oriented NNESSW, which is the same as that of the ridges and of the glaciofluvial belt (Fig. 4). The channel is up to $60 \mathrm{~m}$ deep and its width is only some 200 $\mathrm{m}$. The Giławskie Lake channel passes south- wards into a larger depression (Kalwa Lake), which was also eroded by meltwater (Fig. 4). The total length of the glacial channel system reaches more than $20 \mathrm{~km}$ (Figs 1, 4).

\section{Description of the deposits}

The study site is a large Giławy aggregate pit in which sands and gravels are exploited (Figs 3-4). The pit is approx. $2.5 \mathrm{~km}$ long, up to 
$200 \mathrm{~m}$ wide and $20 \mathrm{~m}$ deep. Sections along the southern and eastern walls were studied. Six sections were studied using the vertical section techniques described by Miall (1996), applying the lithofacies codes of Miall $(1977 ; 1978)$, modified by Zieliński (1995). The deposits are located in several parallel ridges oriented NNE-SSW (Fig. 4). The sedimentary facies are summarised in Table 1 and only noteworthy aspects get attention in the text.

The ridges consist of sand and gravel with sandy diamicton along the flanks. Along the ridge sections gravel occurs intermittently with sand; their grain-size and sedimentary structures are variable. Three lithofacies complexes have been distinguished on top of each other, viz. (from bottom to top) a sandy complex (a), a gravelly complex (b), and a sandy-gravelly complex (c). The diamicton with underlying sandy-gravelly layers with diamicton intercalations is treated as a separate complex (d).

\subsection{Sandy complex a}

This is the most fine-grained unit (Figs 5-6). It consists of three principal sedimentary facies: ripple cross-laminated sand $(S r)$, climbing ripple cross-laminated sand $(S r c)$, and trough cross-stratified sand $(S t)$; minor intercalations of gravel occur. These sedimentary facies have in general no regular distribution, but occur on top of each other in the southernmost part of the ridge. The $S r, S r c$ facies association is dominant in the West, whereas the
$S t, S r$ is more common in the North. Finingupward successions are common, either passing from sand with trough cross-stratification to sand with ripple cross-lamination $(S t \rightarrow S r)$, or from sand with ripple cross-lamination to climbing ripple cross-lamination and finally wavy lamination in very fine sand $(\mathrm{Sr} \rightarrow \mathrm{SrC} \rightarrow$ Sw) (Figs 5B, 6A). Complete successions from ripple cross-laminated sand through climbing ripple-cross laminated sand of $A$ and $B$ types, finishing with wavy laminated fine sand or silty sand, are quite common. Complex a is erosionally cut by the overlying gravel complex b.

\subsection{Gravel complex b}

The gravel complex abruptly overlies sand complex a with local scours (channels) of $1 \mathrm{~m}$ deep. Complex $b$ is the most coarse-grained, and consists of four facies associations: $G h, G m$; $S G p, G m ; S G t, S G p$, and $S h, S p,(G m)$. It is dominated by massive and stratified sand and gravel beds (Figs 5A, 6, 7). Sandy gravel of medium thickness $(30-60 \mathrm{~cm})$ with trough crossstratification $(S G t)$ is one of the most common lithofacies. The troughs are commonly $<40 \mathrm{~cm}$ thick and form cosets of up to $3 \mathrm{~m}$ thick, within which the bed thicknesses decrease upwards from 60 to $20 \mathrm{~cm}$, while the sediment fines upwards. There are commonly small $(<4 \mathrm{~cm})$ clayey clasts among the gravel. These are rounded and show fairly regular margins; some of them are deformed.
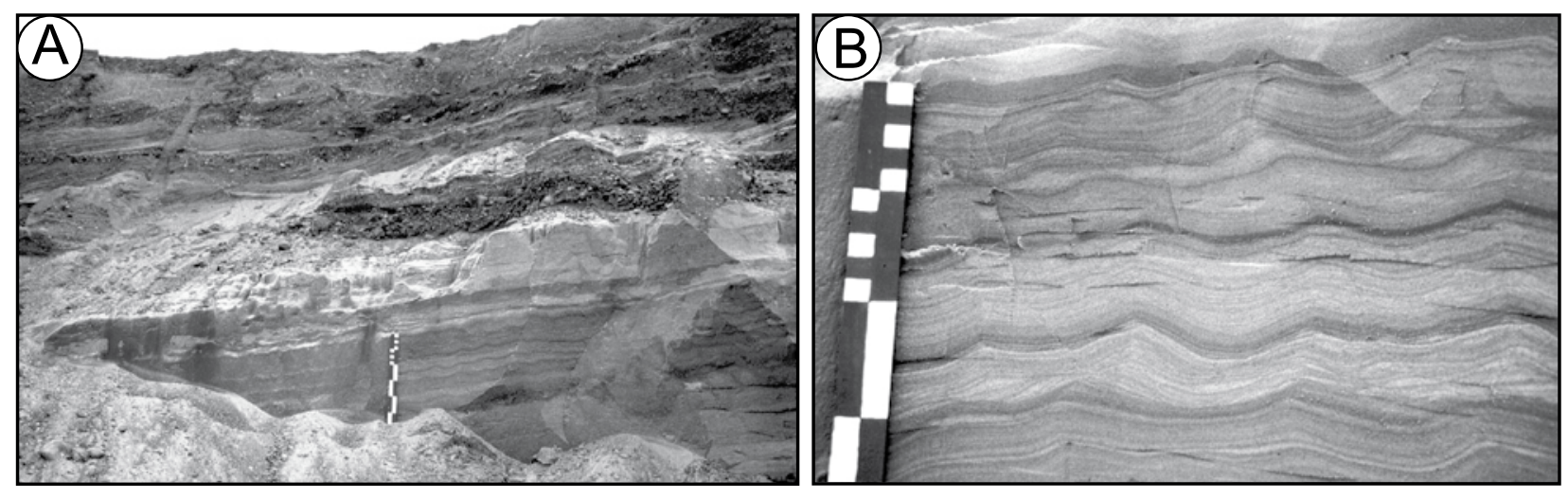

Fig. 5. Details of complexes a and b.

A: Small-scale cross-laminated sand (complex a) overlain by coarse sand and gravel (complex b); B: Sand rhythmites of climbing-ripple cross-lamination and climbing sandy silt with wavy lamination, characteristic of complex a. 
Table 1. Description and interpretation of the sedimentary facies.

\begin{tabular}{|c|c|c|}
\hline Facies & Description & Interpretation \\
\hline$D m m$ & $\begin{array}{l}\text { Massive matrix-supported diamicton } \\
\text { Pebble-sized clasts, angular to well-rounded, sandy- } \\
\text { clayey matrix; bed thickness up to } 50 \mathrm{~cm}\end{array}$ & Cohesive debris flow, flowtill \\
\hline$S D m / S D h$ & $\begin{array}{l}\text { Massive or crudely horizontally stratified diamicton } \\
\text { Medium- and small-scale intercalations in diamic- } \\
\text { ton; poorly sorted clayey/silty sand with granule- } \\
\text { sized gravel }\end{array}$ & Cohensionless liquefied flow \\
\hline Gh & $\begin{array}{l}\text { Crudely horizontally stratified diamicton } \\
\text { Pebble-sized, well sorted gravel in beds up of to } 40 \\
\mathrm{~cm} \text { thick }\end{array}$ & $\begin{array}{l}\text { Highly unsteady, supercritical flow conditions with } \\
\text { pulses in flow strength }\end{array}$ \\
\hline Gm & $\begin{array}{l}\text { Massive gravel } \\
\text { Clast-supported gravel in beds of } 10-30 \mathrm{~cm} \text { thick, } \\
\text { erosional bases; pebble- to cobble-sized, well- } \\
\text { rounded clasts }\end{array}$ & $\begin{array}{l}\text { Large floods in relatively shallow gravel-bed chan- } \\
\text { nels, supercritical flows }\end{array}$ \\
\hline$S G m / G S m$ & $\begin{array}{l}\text { Massive gravelly sand and sandy gravel } \\
\text { Matrix-supported beds of up to } 60 \mathrm{~cm} \text { thick; pebble- } \\
\text { sized clasts, locally oversized }(>20 \mathrm{~cm}) \text {; commonly } \\
\text { normally graded matrix }\end{array}$ & $\begin{array}{l}\text { Large floods in deep channels, hyperconcentrated } \\
\text { flow }\end{array}$ \\
\hline SGh/GSh & $\begin{array}{l}\text { Horizontally stratified sandy gravel and gravelly sand } \\
\text { Usually crudely stratified beds of up to } 20 \mathrm{~cm} \text { thick }\end{array}$ & $\begin{array}{l}\text { Highly unsteady, supercritical flows in shallow } \\
\text { channels }\end{array}$ \\
\hline$S G t$ & $\begin{array}{l}\text { Gravelly sand with trough cross-stratification } \\
\text { Cosets of up to } 3 \text { m thick with normal grading and } \\
\text { with troughs thinning upwards from } 60 \text { to } 20 \mathrm{~cm} \text {; } \\
\text { some clayey clasts }\end{array}$ & 3-D coarse-grained dunes in deep channels \\
\hline$S G p$ & $\begin{array}{l}\text { Gravelly sand with planar cross-stratification } \\
\text { Beds of up to } 50 \mathrm{~cm} \text { thick; some trough cross-strati- } \\
\text { fied sand and massive gravel }\end{array}$ & $\begin{array}{l}\text { Coarse-grained transverse bars in aggrading chan- } \\
\text { nel, dunes in inter-bar zones, gravel sheets on shoals }\end{array}$ \\
\hline$S p$ & $\begin{array}{l}\text { Sand with planar cross-stratification } \\
\text { Small- and medium-scale beds of up to } 20 \mathrm{~cm} \text { thick }\end{array}$ & Transverse bars in sand-bed channel \\
\hline$S l$ & $\begin{array}{l}\text { Sand with low-angle cross-stratification } \\
\text { Beds of up to } 10 \mathrm{~cm} \text { thick }\end{array}$ & $\begin{array}{l}\text { Shallow, fast currents, upper flow regime, evolving } \\
\text { to erosional diminishing of bars and dunes }\end{array}$ \\
\hline Sh & $\begin{array}{l}\text { Horizontally laminated sand } \\
\text { Small-scale beds of up to } 10 \mathrm{~cm} \text { thick. }\end{array}$ & $\begin{array}{l}\text { Traction carpet over the upper plane bed in shallow } \\
\text { channels; or deposition from low bedforms }\end{array}$ \\
\hline St & $\begin{array}{l}\text { Trough cross-stratified sand } \\
\text { Fining-upward cosets of up to } 1 \mathrm{~m} \text { thick, with } \\
\text { troughs of } 10-30 \mathrm{~cm}\end{array}$ & 3-D dune assemblages in deep sand-bed channel \\
\hline Sr & $\begin{array}{l}\text { Ripple cross-laminated sand } \\
\text { Evolves into } 1.5 \mathrm{~m} \text { thick fining-upward successions } \\
S r \rightarrow S r c \rightarrow S w \text {; occurs also as } S r \text { cosets of up to } 20 \mathrm{~cm} \\
\text { thick intercalations of horizontally laminated sand } \\
\text { and and trough cross-stratified sand and gravelly } \\
\text { sand }\end{array}$ & $\begin{array}{l}\text { Shallow currents of moderate power in balance with } \\
\text { rippled channel bed, lower flow regime, waning- } \\
\text { discharge cycles }\end{array}$ \\
\hline Src & $\begin{array}{l}\text { Climbing-ripple cross-laminated sand } \\
\text { Forms part of } 1.5 \mathrm{~m} \text { thick fining-upward successions } \\
S r \rightarrow S r c \rightarrow S w \text {. }\end{array}$ & $\begin{array}{l}\text { Abandoned channels with phases of quiet currents } \\
\text { and considerable amounts of sand in suspension }\end{array}$ \\
\hline$S w$ & $\begin{array}{l}\text { Wavy laminated sand } \\
\text { Final part of the fining-upward successions } \\
S r \rightarrow S r c \rightarrow S w\end{array}$ & Abandoned channels with stagnant water \\
\hline FSh/SFh & $\begin{array}{l}\text { Horizontally laminated sandy silt and silty sand } \\
\text { Small- and medium-scale }(5-20 \mathrm{~cm}) \text { intercalations in } \\
\text { sand lithofacies }\end{array}$ & $\begin{array}{l}\text { Fine-grained suspension in abandoned channels } \\
\text { with cyclic delivery of wash load }\end{array}$ \\
\hline $\mathrm{Fh} / \mathrm{Fm}$ & $\begin{array}{l}\text { Horizontally laminated or massive silt and clay } \\
\text { Small-scale intercalations }(2-10 \mathrm{~cm}) \text { between sand } \\
\text { lithofacies }\end{array}$ & Phases of pelagic suspension \\
\hline
\end{tabular}




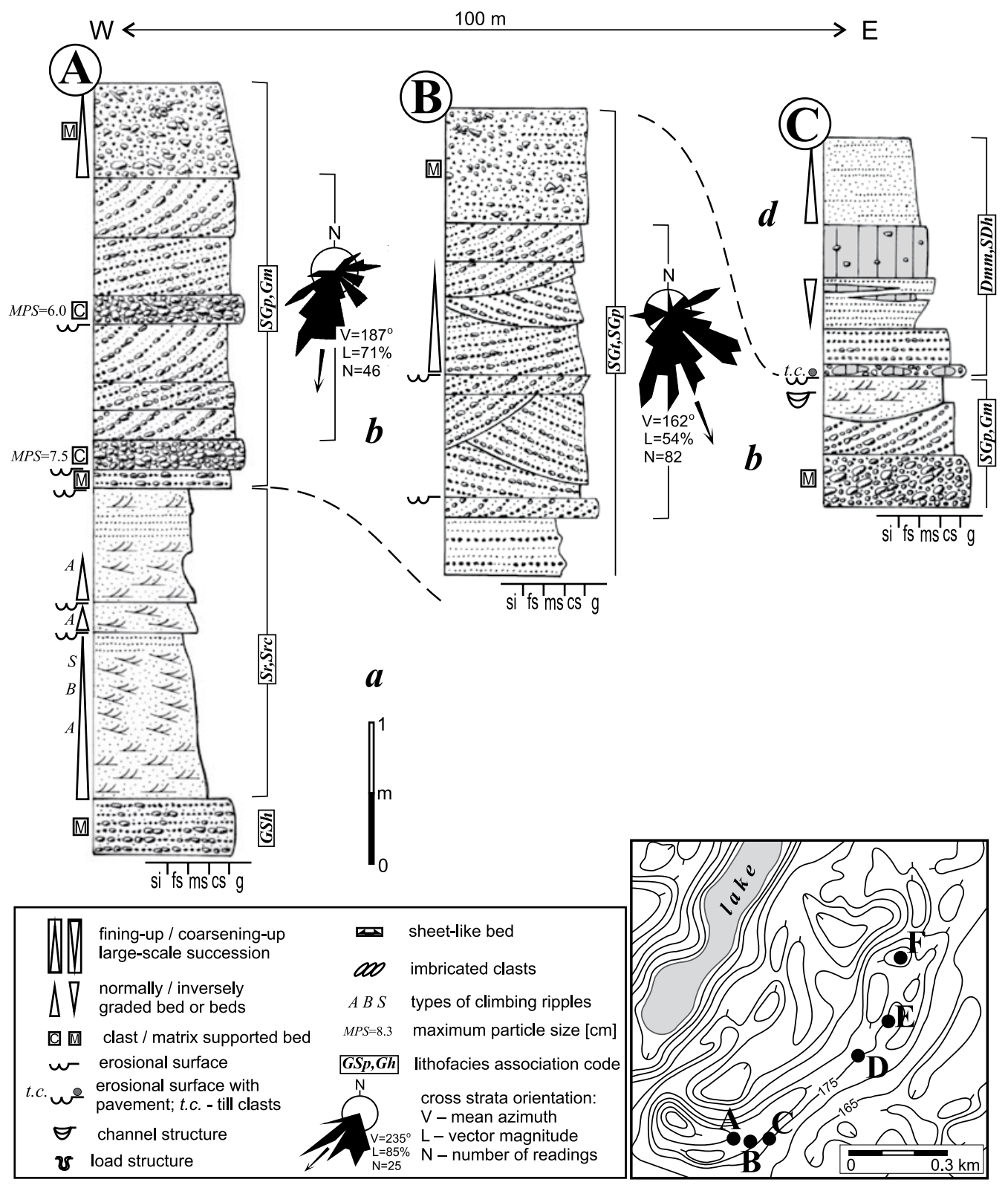

Fig. 6. Sedimentological logs of complexes $a$ and $b$ in the southern part of the esker.

The trough cross-stratified sandy-gravels intercalate with sand and gravel beds of up to 50 $\mathrm{cm}$ thick that show planar cross-stratification $(S G p)$, and with massive gravels. These gravel beds are partly clast-supported, sheet-like beds with thicknesses that do not exceed $30 \mathrm{~cm}(\mathrm{Gm})$ and that have erosional bases; partly they are matrix-supported beds (SGm) of up to $60 \mathrm{~cm}$ thick (Fig. 8A). Some of them are fining upwards. Horizontally stratified gravelly sand $(S G h)$ is a subordinate facies. The transport of the sediments was in general from North to South (Figs 6, 7).
One of the most characteristic features of the gravel complex is the presence of largescale, up to $1.5 \mathrm{~m}$ long, clasts of cross-stratified sand and gravel (Fig. 8C, D). The clasts are elongated and have rounded edges, and their long axes are commonly more or less parallel to the stratification. No deformation occurs below or above the clasts, of which the upper part is sometimes eroded by the overlying sand or gravel beds. 


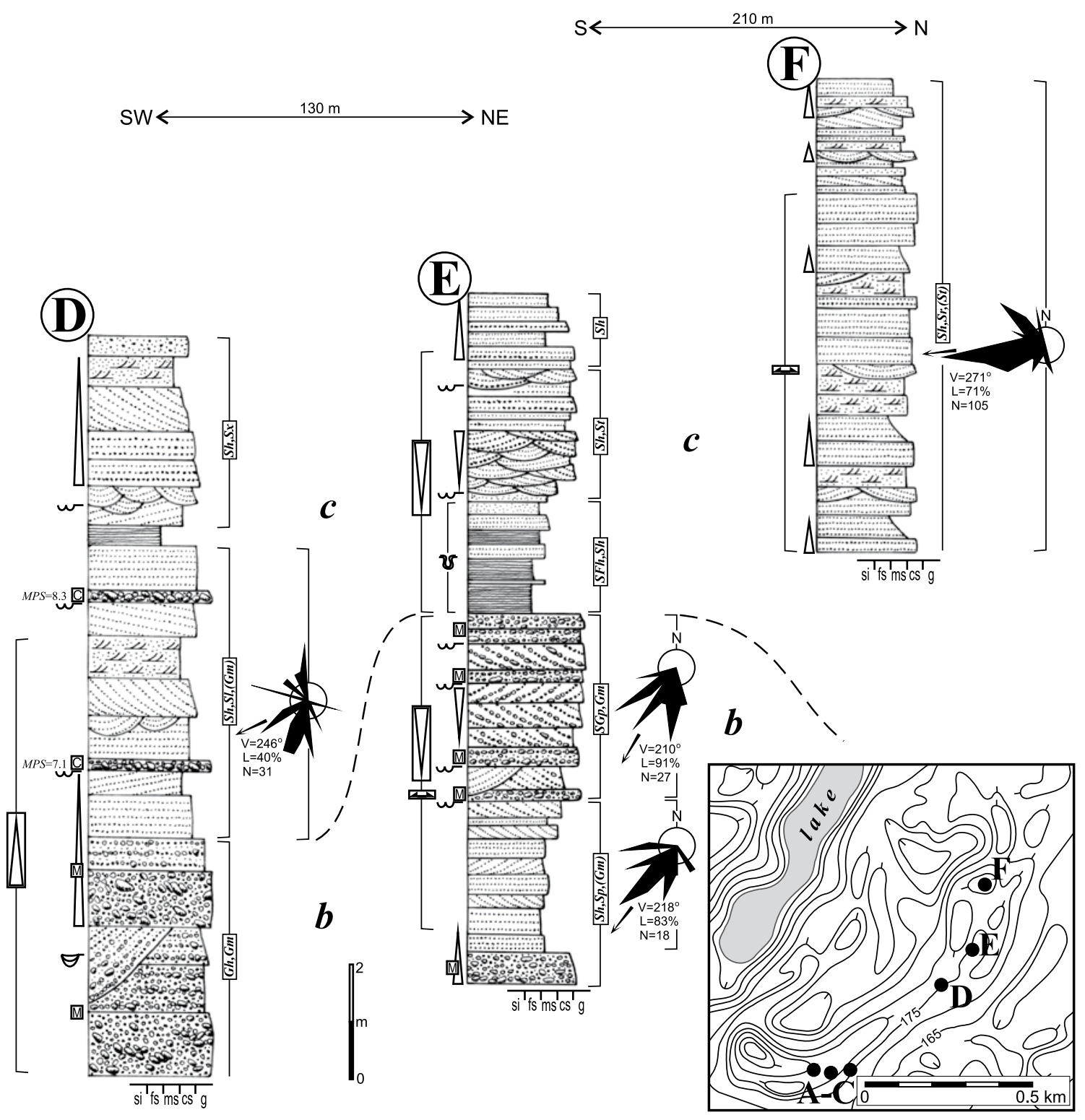

Fig. 7. Sedimentological logs of complexes $\mathrm{b}$ and $\mathrm{c}$ from the northern part of the esker.

\subsection{Sandy-gravel complex c}

The sandy gravel complex overlies the gravel complex. It is much finer-grained than the gravel complex, and the beds are thinner. Sands with horizontal stratification, Sh in beds of up to $10 \mathrm{~cm}$ thick are common; they occur particularly parallel to the base and show a fining upward lamination of medium-grained and fine sand. They intercalate with cosets of trough cross-stratified sands, $S t$, with a coarsening-upward or fining-upward trend (association $S h, S t$ ) (Fig. 7). Locally sand lenses with ripple cross-lamination are present, especially in the $S h, S r,(S t)$ facies association. Intercalation of both gravel beds, Gm, and fine silts, Fh, or sandy silts, FSh, are a characteristic feature of this complex. The gravel beds are much thinner than in complex b: they are not more than $20 \mathrm{~cm}$ thick (Fig. 7). The gravels are clast-supported, massive, and always have erosional bases. Although uncommon, low-angle crossstratified sand is present as beds of up to 10 $\mathrm{cm}$ thick. The silt and silty sand layers are horizontally laminated; their lower parts show usually loading into the underlying sand. The sediment transport was from East to West and from North-East to South-West. 

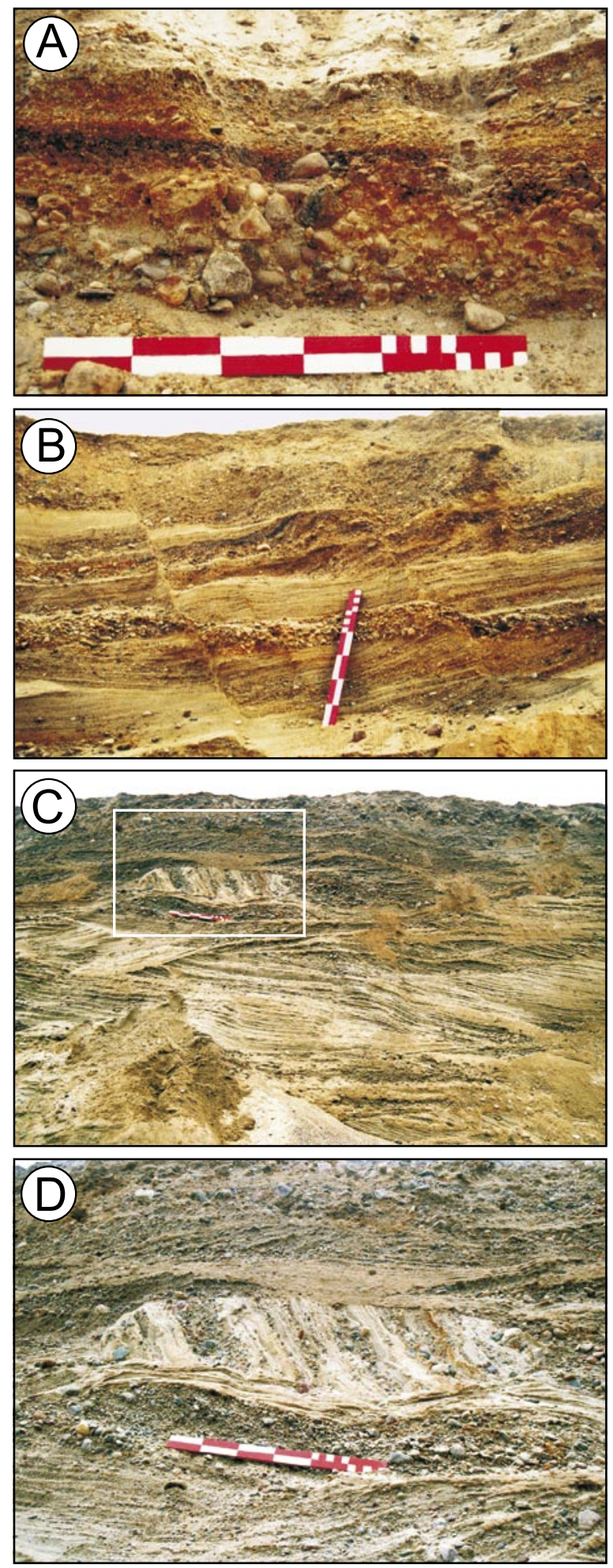

Fig. 8. Complex a.

A: Clast-supported gravel bed with a massive structure; B: Normal faults in the flank of the complex; C: Sandy-gravelly, cross-stratified clast in medium-scale trough cross-stratified sand and gravel. The clast must have been redeposited in a frozen state; D: Details of a sandy-gravelly clast. Note the erosion of its topmost part.
Complex b shows, like complex c, normal faults with offsets of several cm (Fig. 8B).

\subsection{Diamicton complex d}

The gravelly-sandy core of the deposits is flanked by diamicton association $\mathrm{d}$, which consists mainly of matrix-supported diamicton and badly sorted sand (Dmm), and which is up to $1.5 \mathrm{~m}$ thick (Fig. 6C). The basal part of the assemblage is a $10-\mathrm{cm}$ thick, clast-supported diamicton with gravel clasts in a sandy matrix. It is overlain by discontinuous layers of massive sand and diamictic sand with a massive structure or crude horizontal stratification $(S D m, S D h)$. The diamicton bed itself is $<50 \mathrm{~cm}$ thick, massive, with a clayey matrix, and rare gravel clasts of up to 3-4 cm long.

\section{Interpretation}

\subsection{Sandy complex a}

The fine-grained complex a represents an abandoned channel in which sedimentation took place from a current in a steady state. This means that the current's energy did not change over short-term periods and that both the particle concentration and the particles' grain size were in balance with the current velocity (Allen, 1971; Ashley et al., 1982). The ripple crosslaminated sand, Src, originated in shallow, low-energy channels. In quiet periods, large amount of sand particles settled from suspension and were deposited in climbing-ripple cross-laminated cosets. Further decrease of the current energy ultimately culminated in the formation of wavy laminated silty sand, SFw, built by particles that settled from stagnating water in abandoned channels. A few such cycles occurred successively; this resulted in the typical fining-upward climbing-ripple successions (cf. Ashley et al., 1982). The accumulation ratio was moderate, as proven by the thickness $(>1 \mathrm{~m})$ of the fining-upward successions. Lithofacies $S t$ originated in quite deep channels (1-2 $m$ deep) in which megaripples formed in the upper part of the lower flow regime. The pal- 
aeocurrent depth has been assessed from the thickness of trough cross-stratified beds (Nordin \& Algert, 1965; Simons \& Richardson, 1966; Villard \& Church, 2005).

Climbing ripples are common bedforms wherever the topographic gradient of a submerged depositional surface decreases (Jobe et al., 2012), such as on deltas and subaqueous fans (Winsemann et al., 2004), along submarine channel margins (Mutti, 1977), in a marine turbidite setting (Jobe et al., 2012), or even under the high-energy conditions of glacial tunnel (Russell et al., 2003). They have been reported from abandoned or dying channels with increasing loss of suspension (Fielding \& Webb, 1996; Singh \& Bhardwaj, 1991). Small-scale cross-lamination in sand as well as clay layers are known even from subglacial channels at the end of jökulhlaup events, after which the conditions changed back to steady diurnal or seasonal discharge fluctuations (Russell et al., 2003).

\subsection{Gravelly complex b}

The coarse-grained complex $b$ accumulated under completely different conditions. Sedimentation took place in deep channels, with a strongly fluctuating current energy and numerous flood stages. Sandy-gravelly dunes migrated in deep currents (origin of the SGt lithofacies). Large erosional troughs formed locally during flood stages. The gravel-lag beds at the base of some of the troughs indicate that their erosion and infilling were processes that were separated in time: first erosion occurred by powerful currents which left the largest gravel at the bottom of the scoured troughs, while carrying along the less coarse particles of the bed load. When the current energy decreased, the trough was filled with finer-grained sediment. A similar mechanism of scouring has recently been described from a deep-marine slope channel-levée system (Kane et al., 2009), where conglomerates at the bottom of the erosional scours were formed due to significant bedload and tractional reworking, while finer-grained sediments bypassed. The scour was eventually filled with sediments from a later flow. At other times deposition prevailed, which led to the formation and migration of sandy-gravelly transverse bars, with high-angle progradational fronts; these bars show planar cross stratification and constitute lithofacies $S G p$. Lithofacies $\mathrm{Gm}$ (massive gravels) originated during large floods. The clast-supported thinner gravel beds formed under other hydrodynamic conditions than the matrix-supported beds, which are much thicker. The first type developed during turbulent discharge (Costa, 1988) in relatively shallow channels, from supercritical currents under upper plane-bed conditions. The second type originated during high discharge in much deeper channels, where violent currents with a high concentration of coarse-grained suspended load, i.e. particles transported as a hyperconcentrated flow (Smith, 1986; Sohn et al., 1999; Sohn et al., 2002), led to a high sedimentation rate.

\subsection{Sandy gravel complex c}

During sedimentation of sandy gravel complex c, the channels were most of the time shallower, thus providing less opportunity for dune formation. This is indicted by thinner beds, and abundant rippled cosets, $S r$, in the majority of the sedimentary logs. The occasional floods were followed by long periods of average discharge. The presence of horizontally stratified sands, $S h$, points to upper planebed conditions, with migration of low-amplitude bedforms in fast, relatively shallow water (Paola et al., 1989) or downstream migration of in-phase waves (Cheel, 1990). Occasionally, during high-discharge stages, some bars and dunes were affected by erosion (Fielding, 2006) to form low-angle cross-stratified lithofacies, Sl. Such stratification is common in fluvial channels, especially in relatively shallow ones and in channel mouth splays (Folkestad \& Steel, 2001).

\subsection{Diamicton complex d}

The diamicton of complex $\mathrm{d}$ shows characteristics of a flowtill (Zieliński \& Van Loon, 
1996), with the rheological characteristics of a cohesive debris flow. Reworking of till by mass flowage is proven by the small thickness of the diamicton beds, their lenticular shape, and the lateral passage of diamicton into semisorted diamictic sand. The intercalations of diamicton and diamictic sand layers in the lower part of the section indicate redeposition from the slope of the ice.

\subsection{Overview}

The vertical and lateral lithofacies changes in complexes $\mathrm{a}, \mathrm{b}$ and $\mathrm{c}$ indicate frequently shifting positions of the channels. Such avulsion resulted in diminishing current velocities or even stagnant water in some parts of the channels, whereas other parts were incised further at the same time. All these features are characteristic of a braided-channel environment. The palaeocurrent direction was from North and East to South and West. Frequent changes in sediment grain-size, alternation of different flow regimes, and frequent flood stages can be explained satisfactorily only by ablation as the source of water and sediment supply.

The presence of diamictons on the ridge flanks suggests that the braided-channel system existed in a narrow corridor, between ice masses in the West and East, running parallel to the present-day depression of Giławskie Lake (Figs 3, 4). Apart from the flanking diamicton, there are also other sedimentological indications, which will be detailed below, that deposition must have taken place in a laterally confined environment, i.e. an interlobate area.

The large clasts of cross-stratified gravelly sand incorporated into the gravelly-sandy complexes are another significant indication for a confined fluvial environment. These clasts were incorporated into the current as frozen 'boulders', and deposited after a relatively short transport (as indicated by the minor rounding) and buried by a sediment cover before they had been affected by thawing or erosion. Such clasts must occur over the entire length of the Gilawy ridges, as they have also been reported by Mycielska-Dowgiałło et al. (1988) from about $2 \mathrm{~km}$ north of our study site. The clasts are evidence of erosion of frozen banks along the braided channels, during spring or early summer flood stages. The large clasts must have been fallen into the current as a result of undercutting of the banks, and they must have been transported together with the sandy-gravely bedload. Krainer \& Posher (1990) suggest that the transport of frozen diamicton clasts of similar size took place over only a few kilometers, or exceptionally a few tens of kilometers; we think that in our study area transport cannot have been farther that a few kilometers. Clasts transported in a frozen state are more common in sandy silty deposits (70-80\% of silt), but they occur even in gravel floodplains (French \& Shur, 2010). Such clasts that were redeposited as frozen material, definitely prove a periglacial depositional environment (Krainer \& Poscher, 1990). PisarskaJamroży \& Zieliński (in press) recognize the sandy clasts as a typical feature of sedimentary condtions in glacial tunnel.

Small clayey clasts are quite typical of a glaciofluvial environment. They occur commonly in outwash plains (Knight, 1999), ice-contact subaqueous fans (Winsemann et al., 2003) and channel-fill sediments interpreted as channel valley infills (Ghienne \& Deynoux, 1998). They prove the existence of abandoned channels or pools, filled with silty-clayey deposits, being afterwards eroded and transported by a meltwater current.

\section{Discussion}

The ridge core is interpreted as consisting of braided glaciofluvial deposits. Such deposits are typical of glacial outwash plains, which in Poland are equivalent to sandurs (Zieliński, 1993; Zieliński \& Van Loon, 2003). Comparison of the lithofacies spectrum of the ridge deposits under study and the Polish lowland outwashes shows some differences which can shed a light on the palaeoenvironmental conditions of the studied succession. The following lithological features are recognised as essential differences. The large sandy clasts found by us have not been described from the outwash deposits. In addition, till intercalations have not been found 
either in Polish outwash deposits, except for the mountain areas, where the outwash deposits are frequently confined in valleys (Salamon, 2009; Salamon \& Zielinski, 2010). At the study site, both sheet-like till beds up to $0.5 \mathrm{~m}$ thick and thin (order of decimeters) diamictic lenses occur (facies association d in Fig. 6). Moreover, relatively thick packages of sand with climbing-ripple cross-lamination (complex a, see Fig. 6) and packages of horizontally laminated silty sand and sandy silt (complex c, see Fig. 7) are present in the Giławy succession. All these types of deposit are almost absent in the outwashes of northern Poland (Pisarska-Jamroży, 2006; Zieliński \& Van Loon, 2003).

Somewhat less obvious differences are present as well. Generally, the Giławy sedimentary succession is more coarse-grained than the 'standard' sandur. As a rule, Polish outwashes are distinctly dominated by sand, whereas the ratio of gravelly and gravelly-sandy lithofacies to sandy and silty ones is nearly 1 at the Giławy site. The studied succession is characterised by a high frequency of coarse-grained (gravelly and gravelly-sandy) thick (more than $1 \mathrm{~m}$ ) beds, sometimes with a massive structure $(\mathrm{Gm}$ and GSm) and sometimes with trough crossstratification (GSt and SGt) (Figs 6, 7). These lithofacies occur also in Polish outwashes, but their frequency is distinctly lower. On the other hand, the lowermost complex (a) in Giławy is dominated by ripples ( $\mathrm{Sr}$ lithofacies). The frequency of rippled sand beds is lower in Polish outwashes and the packages of rippled sands do not reach similar thickness (more than $2 \mathrm{~m}$ ) as at the Giławy site. Abundant large erosional surfaces occur at Giławy. So many channel-related erosional surfaces (fourth- and fifth-order bounding surfaces accordance to Miall, (1996) are not typical of sandur successions at all. As a rule, outwash erosional surfaces are illdefined; the most evident ones are developed as horizontal gravel lags, and the contours of deep channels are not clear in sandur excavations.

The facts discussed above have significant interpretative consequences. Generally, the style of sedimentation in the studied section is characterised by a higher energy level than typical Polish outwashes. Comparison of the deposits under study and sandur successions also shows considerable palaeoenvironmental differences. The Giławy glaciofluvial environment was characterised by relatively deep channels. Meltwater currents in a confined environment are characterised by both a larger depth and a larger discharge per unit width, i.e. a higher current energy. Each ablation flood results therefore in the development of large troughs and in reworking of bottom sediments. Their formation can be compared with the 'scour pools' described by Siegenthaler \& Huggenberger (1993) from a braided-river environment in confluence areas. At the Giławy site, this is obvious because of the larger thickness of the beds (especially the coarse-grained ones) and the higher frequency of lithofacies with large-scale trough cross-stratification, which are typical of the thalweg of channels.

Another important palaeoenvironmental difference is the hydrological regime. The conduit hydro-environment was characterised by a distinct unsteadiness of the currents (in the sense of discharge and stream power), typical of low-magnitude high-frequency discharge (Marren, 2005). Deposits typical of very fast currents as well as quiet water are often superimposed in the sedimentary profiles under study. The sudden, short-term fluctuations in the hydrological regime also explain another lithological feature, namely that rising-andfalling stage cycles are lacking in the Giławy succession. Such cycles have been quite often found within outwash facies (Aitken, 1998; Fraser \& Cobb, 1982; Olsen \& Andreasen, 1995; Zieliński \& Van Loon, 2003).

All mentioned features can thus be explained by the fact that the glaciofluvial environment was a confined channel artery, i.e. a relatively narrow sedimentary zone bordered by ice walls. The currents rapidly increased in depth and energy during meltwater floods, whereas quiet water conditions (of reservoir type) occurred during low discharge within the ice-sheet tunnel or crevasse. The limited accommodation space dictated that each ablation top-discharge episode resulted in strong erosion of previously accumulated deposits. This erosion was, in turn, followed by extensive ac- 


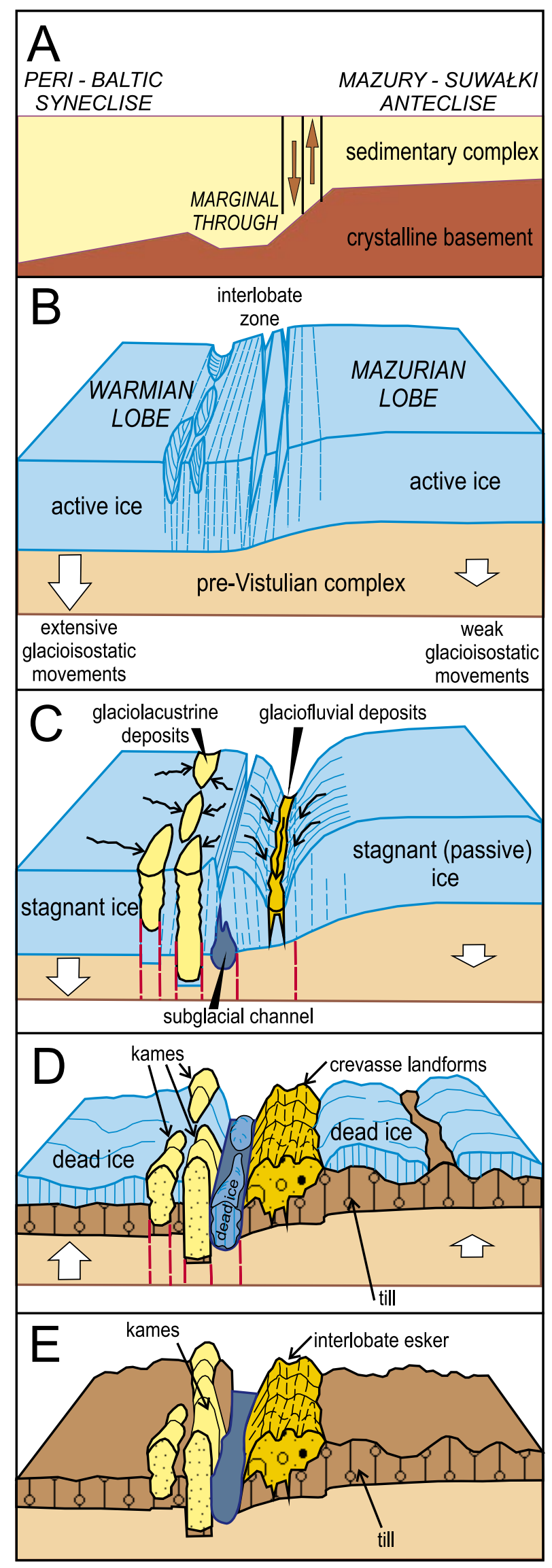

cumulation in the deep current during falling limb of hydrograph.

Another lithological feature of the Giławy deposits - the presence of diamict intercalations - fits well in this explanation. Glaciofluvial deposition took place close to the ice-sheet body, which was the source of abundant mass flows of morainic material. The dense debris flows underwent abrupt 'freezing' in the channel margins during low-discharge phases. Under high-discharge conditions, the mass-flow deposits that had accumulated in the channel margins were eroded and transported over short distances, and then deposited as thin diamictic intercalations within the glaciofluvial succession. The diamicton and diamictic sand beds are much thinner than is typical for the ice-contact environment of the glaciomarginal zone of Polish Pomerania (PisarskaJamroży, 2008), but rather typical of the marginal part of ice crevasse infillings (Godlewska \& Terpiłowski, 2012).

A final question, considering that crevasses must have evolved at both sides of the glacial channel (Fig. 9), is why the landforms at the two sides of the glacial channel developed in different ways, viz. as rounded, hummockylike hills in the West (kames) and long ridges, perpendicular to the ice margin, in the East (eskers). This problem can be explained by the supply of material. The material to the glaciofluvial ridge under discussion must have been supplied, during stagnant-ice conditions, from the mouth of a tunnel in which the majority of the debris was produced by the subglacial system. That stagnant-ice conditions occurred, is obvious not only from the deposit itself but also from the lack of glaciotectonic structures. The ice-confined corridor (crevasse) was stable for a relatively long time, which made the continuous transport of sediments possible.

Fig. 9. Development of the border zone between the two large lobes of the Weichselian ice sheet due to glacioisostatic movements of the bedrock $(\mathbf{A}, \mathbf{B})$. In the axial part of the interlobate zone, a glaciofluvial tunnel developed into an ice crevasse (C). Fine-grained sedimentation predominated in the western side of the interlobate zone (kames), whereas coarse-grained sedimentation (esker) took place in the eastern part $(D, E)$. See the text for details. 
In the western part of the glacial channel, the conditions must have been different. The crevasse system consisted of a few relatively small cracks in the ice where local deposition of supraglacial debris dominated (Fig. 9), which resulted in a differently shaped landform: the sandy, semi-rounded hills west of the channel are kames, while the gravely-sandy ridges (eskers) in the East are built of deposits from the tunnel mouth.

The confined environment was most probably a crevasse in the ice. Geomorphological analysis by Morawski (2009a) revealed the existence of the zone with the same direction of the investigated ridge as other ridges originating from the infilling of ice crevasses. The interlobate area developed due to vertical neotectonic movements (Fig. 9A) related most probably to the mobility of large blocks of the crystalline basement (Morawski, 2009b). This tectonic zone was active during the whole Pleistocene. It was reactivated during the successive glaciations due to the glacioisostatic movements (subsidence during ice transgression and glacioisostatic uplift when the ice sheet retreated). Two lobes originated (Fig. 9B), which most probably moved with different velocities and which reached a different maximum extent (Morawski, 2009a). Most deposition took place after the ice had regionally become stagnant (Fig. 9C-E).

\section{Conclusions}

The sedimentary facies of the sand and gravel ridges within a NE-SW ice-confined corridor are interpreted as representing a braided fluvial framework. Intercalations and laterally occurring layers of diamicton and diamictic sand must be ascribed to deposition within an icewalled, deep conduit. Such an interpretation is supported by the thickness of cross-stratified beds, which require a relatively deep environment. The glaciofluvial corridor is interpreted to have existed during the late Weichselian between two decaying masses of a stagnant ice sheet.

The sedimentary facies of the study site are compared with documented sedimentary facies and the sedimentary architecture of a valley train, sandur outwash deposits, and found to differ on several points. The sedimentary environment was a confined braided channel, with as the most typical lithofacies (a) thick massive gravels, both clast- and matrix-supported; (b) large-scale trough cross-stratified sandy-gravel; (c) intercalations of diamicton layers; (d) presence of diamictic clasts and sandy-gravely clasts dispersed within the deposits. These features allow to distinguish between confined (i.e. in a crevasse channel system) and non-confined (i.e. outwash) environments. The size of the troughs in the trough cross-stratification is much larger in a confined environment. Diamictic clasts, and layers of diamicton as well as large sandy-gravelly clasts have never been reported from outwash plains in Poland.

The ice-walled, interlobate esker deposits coexist with other types of deposits of hummocky type landforms. The complexes of esker ridges are interpreted to have originated in an interlobate area fed through the mouth of a subglacial tunnel.

\section{Acknowledgements}

The research was supported by the Polish Ministry of Science and Higher Education (grant no. N3072852 33, obtained by the first author). The authors are grateful to the reviewers for constructive criticism, which allowed us to thoroughly rewrite some essential parts of an earlier version of this contribution.

\section{References}

Aitken, J.F., 1998. Sedimentology of Late Devensian glaciofluvial outwash in the Don Valley, Grampian Region. Scottish Journal of Geology 34, 97-117.

Allen, J.R.L., 1971. A theoretical and experimental study of climbing-ripple cross-lamination, with a field application to the Uppsala esker. Geografiska Annaler A 53, 157-187.

Ashley, G.M., Southard, J.B. \& Boothroyd, J.C., 1982. Deposition of climbing-ripple beds: a flume simulation. Sedimentology 29, 67-79.

Brennand, T.A. \& Shaw, J., 1996. The Hurricana glaciofluvial complex, Abitibi region, Quebec: its genesis and implications for meltwater regime and ice-sheet dynamics. Sedimentary Geology 102, 221-262. 
Carlson, A.E., Mickelson, D.M., Principato, S.M. \& Chapel, D.M., 2005. The genesis of the northern Kettle Moraine, Wisconsin. Geomorphology 67, 365-374.

Cheel, R.J., 1990. Horizontal lamination and the sequence of bed phases and stratification under upper-flowregime conditions. Sedimentology 37, 517-529.

Costa, J.E., 1988. Rheologic, geomorphic and sedimentologic differentiation of water floods, hyperconcentrated flows and debris flows. In: V.R. Baker, R.C. Kochel \& P.C. Patton (Eds), Flood geomorphology. Wiley Interscience, New York, 113-122.

Eronen, M. \& Vesajoki, H., 1988. Deglaciation pattern indicated by the ice-margin formation in Northern Karelia, eastern Finland. Boreas 17, 317-327.

Evans, D.J.A., 2000. Quaternary geology and geomorphology of the Dinosaur Provincial Park area and surrounding plains, Alberta, Canada: the identifcation of former glacial lobes, drainage diversions and meltwater flood tracks. Quaternary Science Reviews 19, 931-958.

Fielding, C.R., 2006. Upper flow regime sheets, lenses and scour fills: extending the range of architectural elements for fluvial sediment bodies. Sedimentary Geology 190, 227-240.

Fielding, C.R. \& Webb, J.A., 1996. Facies and cyclicity of the Late Permian Bainmedart Coal Measures in the Northern Prince Charles Mountains, MacRobertson Land, Antarctica. Sedimentology 43, 295-322.

Folkestad, A. \& Steel, R.J., 2001. The alluvial cyclicity in Hornelen Basin (Devonian western Norway) revisited: a multiparameter sedimentary analysis and stratigraphic implications. In: O.J. Martinsen \& T. Dreyer (Eds), Sedimentary Environments Offshore Norway - Palaeozoic to Recent. Norwegian Petroleum Society Special Publications (Elsevier, Amsterdam), 10, 39-50.

Fraser, G.S., 1993. Sedimentation in an interlobate outwash stream. Sedimentary Geology 83, 53-70.

Fraser, G.S. \& Cobb, J.C., 1982. Late Wisconsinan proglacial sedimentation along the West Chicago moraine in NE Illinois. Journal of Sedimentary Petrology 52, 473491.

French, H. \& Shur, Y., 2010. The principles of cryostratigraphy. Earth-Science Reviews 101, 190-206.

Ghienne, J.F. \& Deynoux, M., 1998. Large-scale channel fill structures in Late Ordovician glacial deposits in Mauritania, western Sahara. Sedimentary Geology 119, 141-159.

Glanville, C., 1997. Glaciolacustrine and glaciofluvial deposits defining the margins of uncoupling ice lobes in the southeastern midlands of Ireland. Quaternary Science Reviews 16, 685-703.

Godlewska, A. \& Terpiłowski, S., 2012. Transverse, supraglacially derived crevasse infillings in a Pleistocene ice-sheet margin zone (eastern Poland): genesis and sedimentary record. Geomorphology 161-162, 73-81.

Jobe, Z.R., Lowe, D.R. \& Morris, W.R., 2012. Climbingripple successions in turbidite systems: depositional environments, sedimentation rates and accumulation times. Sedimentology 59, 867-898.

Kane, I.A., Dykstra, M.L., Kneller, B.C., Tremblay, S. \& McCaffrey, W.D., 2009. Architecture of a coarse- grained channel-levée system: the Rosario Formation, Baja California, Mexico. Sedimentology 56, 2207-2234.

Knight, J., 1999. Morphology and palaeoenvironmental interpretation of deformed soft-sediment clasts: examples from within Late Pleistocene glacial outwash, Tempo Valley, Northern Ireland. Sedimentary Geology 128, 293-306.

Krainer, K. \& Poscher, G., 1990. Ice-rich, redeposited diamicton blocks and associated structures in Quaternary outwash sediments of the Inn Valley near Innsbruck, Austria. Geografiska Annaler A 72, 249-254.

Lundqvist, J., 1988. Late glacial ice lobes and glacial landforms in Scandinavia. In: R.P. Goldthwait \& C.L. Matsch (Eds), Genetic Classification of Glacigenic Deposits. A.A.Balkema, Rotterdam, 217-225.

Lundqvist, J., 1999. Periodical sedimentation in Scandinavian eskers. GFF 121, 175-181.

Lunkka, J.P. \& Gibbard, P., 1996. Ice-marginal sedimentation and its implications for ice-lobe deglaciation patterns in the Baltic region: Pohjankangas, western Finland. Journal of Quaternary Science 11,377-388.

Mäkinen, J., 2003. Time-transgressive deposits of repeated depositional sequences within interlobate glaciofluvial (esker) sediments in Köyliö, SW Finland. Sedimentology 50, 327-360.

Mäkinen, J. \& Palmu, J.-P., 2008. Collapse of sedimentfilled crevasses associated with floods and mass flows in the proximal zone of the Pernunnummi sandurdelta, III Salpausselkä, SW Finland. Quaternary Science Reviews 27, 1992-2011.

Mańkowska, A. \& Słowański, W., 1978. Geological map of Poland, 1:200,000, sheet Olsztyn. Polish Geological Institute, Warsaw.

Mańkowska, A. \& Słowański, W., 1980. Explanations to geological map of Poland, 1:200,000, sheet Olsztyn. Polish Geological Institute, Warsaw.

Marren, P.M., 2005. Magnitude and frequency in proglacial rivers: a geomorphological and sedimentological perspective. Earth-Science Reviews 70, 203-251.

Miall, A.D., 1977. A review of the braided-river depositional environment. Earth-Science Reviews 13, 1-62.

Miall, A.D., 1978. Lithofacies types and vertical profile models in braided rivers: a summary. In: A.D. Miall (Ed.), Fluvial Sedimentology. Canadian Society of Petroleum Geologists, Memoir 5, 597-604.

Miall, A.D., 1996. The geology of fluvial deposits: sedimentary facies, basin analysis and petroleum geology. SpringerVerlag, Berlin, 582 pp.

Mokhtari Fard, A. \& Gruszka, B., 2007. Subglacial conditions in a branching Saalian esker in north-central Poland. Sedimentary Geology 193, 33-46.

Morawski, W., 2005. Reconstruction of ice sheet movement from the orientation of glacial morpholineaments (crevasse landforms): an example from northeastern Poland. Geological Quarterly 49, 403-416.

Morawski, W., 2009a. Differences in the regional stratigraphy of NE Poland caused by vertical movements due to glacioisostasy. Geologos 15, 235-250.

Morawski, W., 2009b. Neotectonics induced by ice-sheet advances in NE Poland. Geologos 15, 199-217. 
Mutti, E., 1977. Distinctive thin-bedded turbidite facies and related depositional environments in the Eocene Hecho Group (South-central Pyrenees, Spain). Sedimentology 24, 107-131.

Mycielska-Dowgiałło, E., Woronko, B. \& Wijat, T., 1988. Formy i struktury erozyjno-akumulacyjne wód fluwioglacjalnych w korzeniowych partiach ozów [Glaciofluvial forms and erosional/depositional structures in the basal part of eskers]. In: E. Mycielska-Dowgiałło (Ed.), Struktury sedymentacyjne $i$ postsedymentacyjne $w$ osadach czwartorzędowych $i$ ich wartość interpretacyjna [Syn- and postdepositional sedimentary structures in Quaternary deposits and their significance for interpretations]. University of Warsaw, Warsaw, 121-132.

Nordin, C.F. \& Algert, J.H., 1965. Geometrical properties of sand waves - A discussion. In. American Society of Civil Engineers. Proceedings. Journal of Hydraulics Division, 91, HY3, 367-374.

Olsen, H. \& Andreasen, F., 1995. Sedimentology and ground-penetrating radar characteristics of Pleistocene sandur deposits. Sedimentary Geology 99, 1-15.

Paola, C., Wiele, S.M. \& Reinhart, M.A., 1989. Upperregime parallel lamination as the result of turbulent sediment transport and low-amplitude bed forms. Sedimentology 36, 47-59.

Paterson, J.T. \& Cheel, R.J., 1997. The depositional history of the Bloomington complex, an ice-contact deposit in the Oak Ridges Moraine, southern Ontario, Canada. Quaternary Science Reviews 16, 705-719.

Pisarska-Jamroży, M., 2006. Transitional deposits between the end moraine and outwash plain in the Pomeranian glaciomarginal zone of NW Poland: a missing component of ice-contact sedimentary models. Boreas 35, 126-141.

Pisarska-Jamroży, M., 2008. Zonation of glaciomarginal environment inferred from Pleistocene deposits of Mysliborz Lakeland, NW Poland. Geografiska Annaler 90A, 237-249.

Pisarska-Jamroży, M., \& Zieliński, T., in press. Specific erosional and depositional processes in a Pleistocene subglacial yunnel in the Wielkopolska region, Poland. Geografiska Annaler; A; doi: 10.1111/j.14680459.2012.00466.x.

Punkari, M., 1997. Glacial and glaciofluvial deposits in the interlobate areas of the Scandinavian ice sheet. Quaternary Science Reviews 16, 741-753.

Russell, H.A.J., Arnott, R.W.C. \& Sharpe, D.R., 2003. Evidence for rapid sedimentation in a tunnel channel, Oak Ridges Moraine, southern Ontario, Canada. Sedimentary Geology 160, 33-55.

Salamon, T., 2009. Origin of Pleistocene outwash plains in various topographic settings, southern Poland. Boreas 38, 362-378.

Salamon, T. \& Zieliński, T., 2010. Unusual development of sandur sedimentary succession, an example from the Pleistocene of S Poland. Geologos 16, 83-99.

Siegenthaler, C. \& Huggenberger, P., 1993. Pleistocene Rhine gravel: deposits of a braided river system with dominant pool preservation. In: J.L. Best \& C.S. Bristow (Eds), Braided Rivers. Geological Society of London, Special Publication 75, 147-162.
Simons, D.B. \& Richardson, E.V., 1966. Resistance to flow in alluvial channels. US Geological Survey Professional Paper 422-J, 61 pp.

Singh, A. \& Bhardwaj, B.D., 1991. Fluvial facies model of the Ganga river sediments, India. Sedimentary Geology 71, 135-145.

Smith, G.A., 1986. Coarse-grained nonmarine volcaniclastic sediment: terminology and depositional process. Bulletin of the Geological Society of America 97, 1-10.

Sohn, Y.K., Choe, M.Y. \& Jo, H.R., 2002. Transition from debris flow to hyperconcentrated flow in a submarine channel (the Cretaceous Cerro Toro Formation, southern Chile). Terra Nova 14, 405-415.

Sohn, Y.K., Rhee, C.W. \& Kim, B.C., 1999. Debris flow and hyperconcentrated flood-flow deposits in an alluvial fan, NW part of the Cretaceous Yongdong Basin, central Korea. Journal of Geology 107, 111-132.

Stokes, C.R. \& Clark, C.D., 2001. Palaeo-ice streams. Quaternary Science Reviews 20, 1437-1457.

Veillette, J.J., 1994. Evolution and paleohydrology of glacial lakes Barlow and Ojibway. Quaternary Science Reviews 13, 945-971.

Villard, P.V. \& Church, M., 2005. Bar and dune development during a freshet: Fraser river estuary, B.C., Canada. Sedimentology 52, 737-756.

Warren, W.P. \& Ashley, G.M., 1994. Origin of ice-contact stratified ridges (eskers) of Ireland. Journal of Sedimentary Research A64, 433-449.

Weaver, L. \& Arnaud, E., 2011. Polyphase glacigenic deformation in the Waterloo Moraine, Kitchener, Ontario, Canada. Sedimentary Geology 235, 292-303.

Winsemann, J., Asprion, U. \& Meyer, T., 2004. Sequence analysis of early Saalian glacial lake deposits (NW Germany): evidence of local ice margin retreat and associated calving processes. Sedimentary Geology 165, 223-251.

Winsemann, J., Asprion, U., Meyer, T., Schultz, H. \& Victor, P., 2003. Evidence of iceberg-ploughing in a subaqueous ice-contact fan, glacial Lake Rinteln, NW Germany. Boreas 32, 386-398.

Zieliński, T., 1993. Sandry Polski pótnocno-wschodniej - osa$d y$ i warunki sedymentacji. (Outwash plains of NE Poland - sediments and depositional processes). Prace Naukowe Uniwersytetu Śląskiego 1389, 96 pp.

Zieliński, T., 1995. Kod litofacjalny i litogenetyczny konstrukcja i zastosowanie. (Lithofacies and genetic codes: construction and application). In: E. MycielskaDowgiałło \& J. Rutkowski (Eds), Badania osadów czwartorzędowych. (Investigations of Quaternary sediments). University of Warsaw, Warsaw, 220-235.

Zieliński, T. \& Van Loon, A.J., 1996. Characteristics and genesis of moraine-derived flowtill varieties. Sedimentary Geology 101, 119-143.

Zieliński, T. \& Van Loon, A.J., 2003. Pleistocene sandur deposits represents braidplains, not alluvial fans. Boreas 32, 590-611.

Manuscript received: 3 January 2012 Revision accepted: 31 May 2012 